\title{
ß-クロルクロトニルアミノ基を有する反応性染料†
}

(昭 和 36 年 9 月 30 日 受 理)

\section{山瀬威郎・北尾弟次郎・黒木宣崖・小西謙 三*}

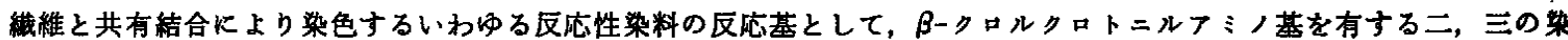
料を合成し、綟，ナイロン，ビスュースレーヨンに対する反応性染料としての適用性，色調，堅口ウ度などを調くた。な 和既報のクロルアセチルフミ/基, クロルプロピオニルフミ/基を有する反応性染料との比较をなったった。

本染料はフミノ基を有する水溶性フゾ染料と $\beta$ ークロルクロトン酸クロリドとの縮合によって合成した。これらの染料 を用いて, 上述の瀻維をアルカリ性あるい酸性染色後フルカリ処理（リン酸第三ナトリウム）により反応させ, 未固着 染料はソーピングにより䟻去した。

これらの染料の染色性は非常に良好であり，固着度も一部を除いては既報よりるすぐれていた。色調は黄，だいだい， 赤，紫，青色系縄である。堅口ウ度も，洗たく，摩擦，日光ともに非常にすぐれていた。染料一織維間の共有結合生成は 既報と同様の方法で確かめた。

われわれはさきに多ロルアセチルアミノ基")，およびクロルブ ロピオニルアミノ基坚を有する反応性水溶性染料で非常に良好な 結果をえているので, この系列の反応性染料をさらに拡張すへく 反応性基として， $\beta$-クロルクロトニルアミノ基を選び, この基を 有する氷溶性アゾ染料を合成してビスコースレーヨン，絹，ナイ ロンに対する適用性，色調，堅ロウ度などを考察した。体染料 としては染色方法を简単にし分解染料の除去を容易飞するため, 染料分子中にスルホン酸基を溥入した水溶性染料を用いた。

及ークロルクロトン酸エステルとアンモニアとの反応で $\beta$ ーアミ ノクロトン酸エステルが党られること（因 1) 性, Shriner ら

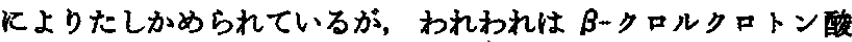
アニリドとエチルアルコールとの反庒で $\beta$-ェトキシクロトン酸 アニリドがえられることをたしかめた（図 2)。したがって ロルクロトニルアミノ基を有する染料は $-\mathrm{NH}_{2}$ おび - $\mathrm{OH}$ を有 する絾維と図 3 のごとき形式で反応すると思われる。

$$
\begin{aligned}
& \left(\mathrm{H}_{6} \mathrm{C}_{2}\right)_{2} \mathrm{~N}\left(\mathrm{CH}_{2}\right)_{2} \mathrm{CO}_{2} \mathrm{CH}=\mathrm{Cl}-\mathrm{CH}_{8} \stackrel{\mathrm{NH}_{3}}{\longrightarrow} \\
& \left(\mathrm{H}_{6} \mathrm{C}_{2}\right)_{2} \mathrm{~N}\left(\mathrm{CH}_{2}\right)_{2} \mathrm{CO}_{2} \mathrm{CH}=\stackrel{\stackrel{\mathrm{C}}{\mathrm{C}}-\mathrm{CH}_{2}}{\mathrm{CH}_{3}}
\end{aligned}
$$

因 1 ßークロルクロトン酸エステルとアンモニフとの反応

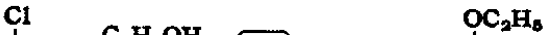

$\longrightarrow-\mathrm{NH} \cdot \mathrm{CO} \cdot \mathrm{CH}=\stackrel{\mathrm{C}}{\mathrm{C}}-\mathrm{CH}_{3} \stackrel{\mathrm{C}_{2} \mathrm{H}_{8} \mathrm{OH} \longrightarrow \longrightarrow}{\longrightarrow} \longrightarrow \mathrm{NH} \cdot \mathrm{CO} \cdot \mathrm{CH}=\stackrel{\mathrm{OC}}{\mathrm{C}}-\mathrm{CH}_{2} \mathrm{H}_{8}$

図 2 Bークロルクロトン酸フニリドと エチルフルコールをの反庆

Cl

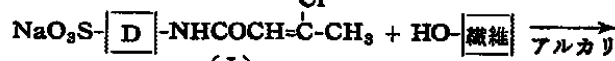

$$
\mathrm{NaO}_{3} \mathrm{~S}-\mathrm{D}-\mathrm{NHCCOH}=\mathrm{C}-\mathrm{CH}_{3}
$$

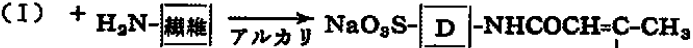
NH- 赫㱷 $\mathrm{OH}$

(I) $+\mathrm{HOH} \underset{\nexists ル カ y}{\longrightarrow} \mathrm{NaO}_{3} \mathrm{~S}-\mathrm{D}-\mathrm{NHCOCH}=\mathrm{C}-\mathrm{CH}_{8}$

D 快尊色有機分子をあらわす

図 3 B-クロルクロトニルアミノ基を有する 水溶性染料の反応形式

†本報告を「反応性染料に関する研究（第 14 報)」とする.

* 大阪府立大学工学部応用化学教室 : 堺市百舌鳥梅町。

1) 北尾, 黒木, 小酉, 工化 63, 133 (1960).

2) 北尾, 黒木, 小西, 工化 63, 137 (1960).

3) R.L.Shriner, L.S. Keyser, J. Am. Chem. Soc. 60, 286 (1938).
すなわち，セルロース系紻維との反応ては（I）か（II）に，

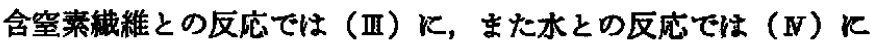
なるすのと考えられる。（II）あるいは（而）で生じた $\alpha, \beta-1$ 飽和プロ パニル化合物がさらに活性水素化合物と付加反応を行な らことも考えられるが，ポバールとの反応で架棈結合が生じない ことよりその可能性は少ないようである。すなわち，この染料を 含むポバール水溶液を食塩で飽和された水酸化ナトリウム液に投 入すると表面にフィルムが生成するが，このフィルムは氷と意沸 $\mathrm{CH}_{3} \mathrm{COCH}_{2} \mathrm{COOC}_{2} \mathrm{H}_{3}+\mathrm{PCl}_{5} \longrightarrow \mathrm{Cl} \cdot \mathrm{CO} \cdot \mathrm{CH}=\mathrm{C}-\mathrm{CH}_{3}$ $\mathrm{NaO}_{3} \mathrm{~S}-\mathrm{D}-\mathrm{NH}_{2}+\mathrm{Cl} \cdot \mathrm{CO} \cdot \mathrm{CH}=\mathrm{C}-\mathrm{CH}_{8} \frac{\text { ビyジン }}{\text { フ๘トン中 }}$ $\mathrm{NaO}_{3} \mathrm{~S}-\mathrm{D}-\mathrm{NH} \cdot \mathrm{CO} \cdot \mathrm{CH}=\mathrm{C}-\mathrm{CH}_{\mathrm{S}}$

图 4 衤クロルクロトニルアミノ基を有する 反応性染料の合成過程
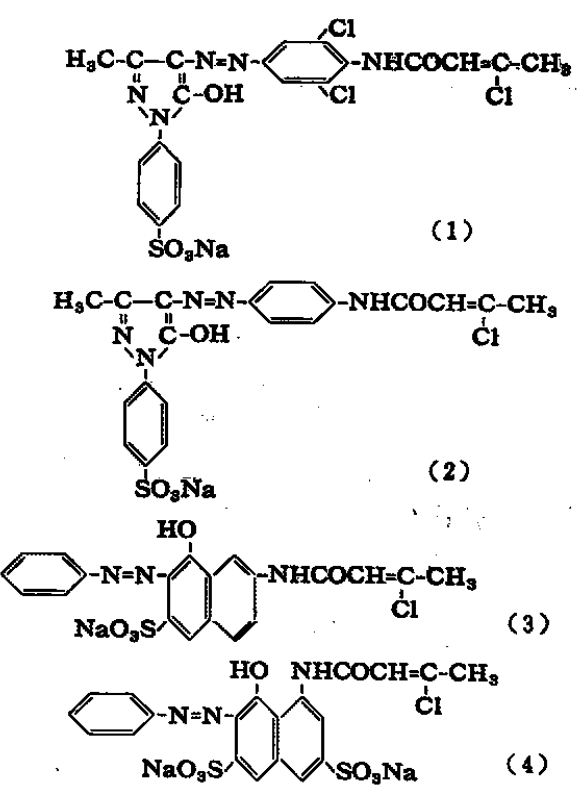
HO $\mathrm{NHCOCH}=\mathrm{C}-\mathrm{CH}_{3}$<smiles>CO[S](=O)(O[Na])O[Na]</smiles>

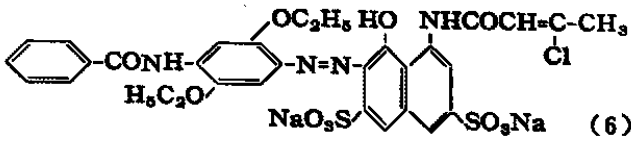

図 $5 \beta$ タークロルクロトニルフミノ基を有する水溶性染料 
すると容易に溶解した。したがって架橋結合は生じていなかっ た。なお樴維との共有結合が生成されていることは既報の $\beta$-ク ロルエチルスルホンアミド染料》) の場合と同様にして確かめた。

この染料はベンゼン溶媒中で五塩化りンとアセ卜酷酸エチルエ ステルとの反応炕より得られるßークロルクロトン酸クロリドに アミノ基を有する水溶性アヴ染料をアセトン中でピリシシン（脱塩

酸唷）とともに反応させて合成した（図 4)。

合成した染料㥗 5 に示す（1)〜（6）である。

これらの染料の収率，性質は表1のようになる。

表 $1 \beta$ タークルクロトニルフミノ基を有する 水溶性染料の収率, 性管

\begin{tabular}{|c|c|c|c|c|c|c|}
\hline \multirow{2}{*}{ 染料 } & \multirow{2}{*}{$\begin{array}{l}\text { 取平 } \\
(\%)\end{array}$} & \multirow{2}{*}{$\begin{array}{l}\text { 染料 } \\
\text { の色 }\end{array}$} & \multicolumn{2}{|c|}{ 䆙秦分析 $(\%)$} & \multicolumn{2}{|c|}{ 吸取媔大值* } \\
\hline & & & 测定 & 䑩集 & $\lambda_{\max }(m \mu)$ & $\varepsilon_{\max } \times 14^{-4}$ \\
\hline 1 & 81.6 & 費苯 & 12.92 & 13.32 & 398 & 2.480 \\
\hline 2 & 83.3 & 贯 & 14.57 & 14.50 & 448 & 2.870 \\
\hline 3 & 85.3 & 赤 & 8.98 & 9.23 & 503 & 2.540 \\
\hline 4 & 89.1 & 亦柴 & 7.35 & 7.80 & 522 & 4.020 \\
\hline 5 & 92.0 & 暗赤柴 & 9.55 & 9.05 & 538 & 4.000 \\
\hline 6 & 84.4 & 采 & 7.20 & 7.54 & 556 & 3.530 \\
\hline
\end{tabular}

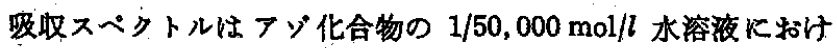
る可視吸収スペクトルを日立分光光度計 EPU-2 型で測定(常温)

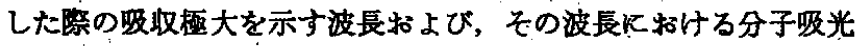
保数を示した。

表 $2 \beta$ タークルクロトニルフミノ基を有する 水溶性染料の染色結果

\begin{tabular}{|c|c|c|c|c|c|c|c|}
\hline \multirow{2}{*}{$\begin{array}{l}\text { 染料 } \\
\text { 䈏号 }\end{array}$} & \multicolumn{3}{|c|}{ 䊘（フルカリ性染色） } & \multicolumn{4}{|c|}{ 和（酸姓染色） } \\
\hline & 色 & 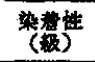 & 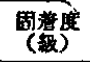 & 色 & 解 & 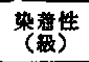 & 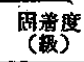 \\
\hline 1 & 贵 : & 5 & 2 & $k s$ & 黄 & 5 & 3 \\
\hline 2 & Kぶ黄だいだい & 5 & 2 & 黄 & 茶 & 5 & 4 \\
\hline 3 & 赤 & 5 & 3 & $k$ & 赤 & 5 & 4 \\
\hline 4 & 業味 & 5 & 4 & 明るい & 赤兟 & 5 & $4 \sim 5$ \\
\hline 5 & 矼味紫 & 5 & 3 & 暗 い & 、柴 & 5 & $4 \sim 5$ \\
\hline 6 & 暗い青 & 5 & 3 & 暗 & 育 & 5 & 4 \\
\hline \multirow{2}{*}{$\begin{array}{l}\text { 架料 } \\
\text { 黄号 }\end{array}$} & \multicolumn{3}{|c|}{ ナイロン (アミテン $)$} & \multicolumn{4}{|c|}{ ビスュースレーョン } \\
\hline & 解 & 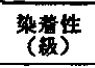 & 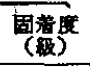 & 色 & 穊 & 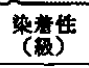 & 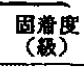 \\
\hline 1 & にぶ荻だいだい & 4 & 4 & 穿 & & 5 & 3 \\
\hline 2 & Kぶ赤珠だいだい & 4 & $4 \sim 5$ & 赤来 & 荡 & 5 & 3 \\
\hline 3 & 赤＼cjkstart茶 & 5 & 4 & 黄味 & 赤 & 5 & $3 \sim 4$ \\
\hline 4 & Kぷ赤禁 & 4 & $4 \sim 5$ & こい & 跦赤 & 5 & 4 \\
\hline 5 & 暗い笄味兏 & 5 & 5 & 第 & & 5 & 3 \\
\hline 6 & 暗 い肙 & 5 & $4 \sim 5$ & Ks s & 青 & 5 & 3 \\
\hline
\end{tabular}

表 3 Bークロルクロトニルフミノ基を有する 水溶性染料の堅口ウ度試験結果

\begin{tabular}{|c|c|c|c|c|c|c|}
\hline \multirow{2}{*}{$\begin{array}{l}\text { 染料 } \\
\text { 暗母 }\end{array}$} & \multicolumn{3}{|c|}{ 䅌（アルカリ妵架色） } & \multicolumn{3}{|c|}{ 樘（酸染染色） } \\
\hline & $\begin{array}{l}\text { 晃 } \\
\text { (期) }\end{array}$ & $\begin{array}{l}\text { 先たく } \\
90^{\circ} \mathrm{C} \text { (和) }\end{array}$ & 雤) & $\begin{array}{l}\text { 量 } \\
\text { (激) }\end{array}$ & 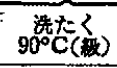 & 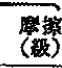 \\
\hline 1 & $6<$ & 5 & 5 & $6<$ & 5 & 5 \\
\hline 2 & 6 & 5 & 5 & $6<$ & 5 & 5 \\
\hline 3 & $6<$ & 5 & 5 & 6 & 5 & 5 \\
\hline 4 & $6<$ & 5 & 5 & 5 & 5 & 5 \\
\hline 5 & $6<$ & 5 & 5 & 6 & 5 & 5 \\
\hline \multirow[t]{2}{*}{6} & $6<$ & 5 & 5 & 6 & 5 & 5 \\
\hline & \multicolumn{3}{|c|}{ ナイロン (フミラン) } & \multicolumn{3}{|c|}{ ピスヌースレーヌン } \\
\hline 番舟 & 是萎 & $90^{\circ} \mathrm{C}(\mathrm{s})$ & (6) & 是光 & 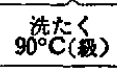 & 繁被 \\
\hline 1 & $6<$ & 5 & 5 & $6<$ & 5 & 5 \\
\hline 2 & $5 \sim 6$ & 5 & 5 & $6<$ & 5 & 5 \\
\hline 3 & $6<$ & 5 & 5 & $6<$ & 5 & 5 \\
\hline 4 & $4 \sim 5$ & 5 & 5 & $6<$ & 5 & $\mathbf{5}$ \\
\hline 5 & $4 \sim 5$ & 5 & 5 & $6<$ & 5 & 5 \\
\hline 6 & 6 & 5 & 5 & $6<$ & 5 & 5 \\
\hline
\end{tabular}

4) 山瀬, 北尾, 黑木, 小西, 工化 65，217 (1962).
本系統の染料 $((1) \sim(6))$ を用いて，ビスコースレーヨン， 絧を中性，ボウ硝添加によって染色しまた，ナイロン（アミラ ン)，絹を酶酸酸性にして染色し，のちに前者は炭酸ナトリウム， 後者はリン酸第三ナトリウムーボウ硝の希溶液で処理して反応さ せた。な抹未結合染料（分解染料）はソーピングによって除去し た。これらの染色結果を表 2 に, 堅口ウ度試験結果を表 3 に示す。

色調は日本色彩研究所「色の標準」占に上った。染着性は C.I. Acid Red 1 火相当する化合物でアセテートを $2 \%$ 染めした際 飞えられる染色物の濃度を標集 5 級とし、アルカリ固着後水洗し た各サンプル布の濃度がこれと同程度のものを 5 級, やや劣るる のを 4 极，劣るすのを 3 級，やや染着性を有するものを 2 級、ほ とんど染着しないすのを 1 䄲とした。固着度は染着性度の变化の ないるのを 5 級，わすか比変化するるのを 4 級，変化のあるすの を 3 級，变化の著しいものを 2 級，变化の非常に著しいるのを 1 級とした。なおンーピング処理前の染色物で染着性を, ソーピン グ処理後のもので色調㧍よび堅ロウ度を調べた。

洗たく堅ロウ度拉よび摩擦堅口ウ度は JIS K-4002 Kより, 日 光堅ロウ度は東洋理化製フェードテスターFA-1 型を用い，学 振青色標集布との比較による級数を示した。可検布の検查はすべ て眼との距離を $60 \mathrm{~cm}$ として北側の空際の光線のもとで肉眼に より判定した。

表 2 に示したように，色調は黄，だいだい，赤，紫，青色系の 範囲のものであり，非常に良好な染色結果がえられている。すな わちナイロンでは今までのクロルアせチルフミノ染料，クロルプ ロピオニルアミノ染料より少し劣っているようであるが，綗では これらの染料よりかなりすぐれて招り，特にビスコースレーヨン ではきわめて良好であった。すた表 3 のごとく，日光，洗たく，

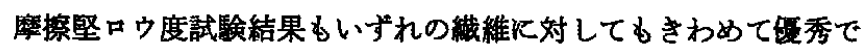
ある。

ナイロンは編，ビスュースレーヨンと比較すると固着度，色調 の鮮明度の点で若干劣っているようである。網の場合酸性染色後 アルカリ処理をしたるのと、アルカリ性染色によってえられたる のと比較すると，前者は固着度は咀好であるが鮮明度は若干劣っ ている。ビスコースレーシンで鮮明といら点で，隹かのるのよ り極めてすぐれていた。特に染料 (1)，(3)，(4) などは優秀 である。

\section{実験 の 部}

\section{染料中間体の合成}

$\beta$-クロルクロトン酸クロリド9）無水ベンゼン $100 \mathrm{~g}$ 溶媒中に

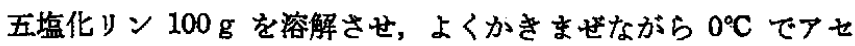
卜酢酸エチルメステル $100 \mathrm{~g}$ を 4 時間で滴下さす。その後水浴上 で 1 時間かきませ，続いて室温で 1 時間かきまぜを続ける。さら に温度を $50^{\circ} \mathrm{C}$ に上年し，かきぜをはげしくして発生するガス を除去する(約 1 時間)。溶液ははじめ黄色（濁っている）から次 第に透明になり，加熱かきまぜてつて赤変し，最後には暗赤色 となる。

上記の方法により兄られた腤赤色溶液を 80 90 9 Cでベンゼン を追出し， 122 140 C で蒸留物 $\beta$ ークロルクロトン酸クロリドを 兄る。無色透明，強い刺激臭ある液体。取率 $66 \%$ (文献值 87.8 $\%$ )。

5）日本色彩研究所「色の標準」(1954) 東京 
$\boldsymbol{\beta}$-クロルクロトン酸アニリド・ $\boldsymbol{\beta}$ アクロルクロトン酸クロリド $7 \mathrm{~g} ， ア ニ リ ン 10 \mathrm{~g}(2 \mathrm{~mol})$ を混合し 3 時間かきませ罯流を続け る。その後これに炭酸ナトリウム水溶液を加光生成したアニリン 塩酸塩をアニリンにする。このアニリンは水蒸気蒸留によって除 去した。生成物はエチルアルコールで再結晶。針状結晶がえられ る。 $\mathrm{mp} 108^{\circ} \mathrm{C}$, 取率 $70 \%$ 。

$\beta$-エトキシクロトン酸アニリド $\quad \beta$ ークロルクロトン酸アニリ ド $5 \mathrm{~g}$ をエチルアルコール $50 \mathrm{ml}$ 中に溶かし，水酸化カリウム $2 \mathrm{~g}$ を加えて 3 時間かきまぜ遗流を行な5。過剩のアルコールを 除去すると，白色結晶がえられる。エチルアルコールで再結晶。 $\mathrm{mp} 102^{\circ} \mathrm{C}$, 収率 $60 \%$ 。
分 析 犆
$\mathrm{C}: 68.03, \mathrm{H}: 7.11, \mathrm{~N}: 6.94$
$\mathrm{C}_{12} \mathrm{H}_{16} \mathrm{NO}_{2}$ としての計算值
$\mathrm{C}: 70.24, \mathrm{H}: 7.31, \mathrm{~N}: 6.83$

母体染料の合成

既報《)と同様にして合成し，精製した。

母体染料と $\beta$-クロルクロトン酸クロリドの縮合

アミノ基を有する母体染料 $3 \mathrm{~g}$ をアセトン $50 \mathrm{ml}$ 中に分散さ せ，これに $\beta$-クロルクロトン酸クロリド $3 \mathrm{~g}$ を徐々に加え（こ の時温度は約 $10^{\circ} \mathrm{C}$ 上年する) さらに脱塩酸珴としてビリジン 1 $\mathrm{ml}$ を加え $58 \sim 59^{\circ} \mathrm{C}$ で 3 時間かきまぜ還流を続ける。生成した 染料はロ別後アセトンで洗浄し䇉燥した。その取率，色娚，窒素 分析值，吸収スペクトル値は表1飞示した。

染色 用いた布は 100\%-䋧（デシン），100\%ーアミランつやけ し平織布就よび 100\%ービスコースレーヨン平織布であった。浴 比は 20:1であり，染料は布に対しそれぞれ 5 wt\% 用いた。

6) Autenrieth, Ber. 29, 1666, 1668 ; Autenrieth, Spiess, ibid. 34, 196.
糄（アルカリ性染色）染料 $50 \mathrm{mg}$ をペースト状となし，水 $20 \mathrm{ml}$ に溶解させ試験布 $1 \mathrm{~g}$ をつける。これ無水ボウ硝 $6 \mathrm{~g}$ を 3 回䎲わたって加え，20 分間ときどきかませがら常温に

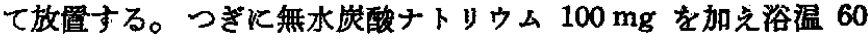
${ }^{\circ} \mathrm{C}$ で 30 分間染着，その後水浴を $100^{\circ} \mathrm{C}$ に上界し，1 1 時間反庍 固着させる。水洗，䡎燥。

編（酸性染色）染料 $50 \mathrm{mg}$ をベースト状とし; 水 $20 \mathrm{mi} に$ 溶解させ $95 \%$ 米酰酸 $0.2 \mathrm{ml}$ を加之試験布 $1 \mathrm{~g}$ をつける。东浴 $90^{\circ} \mathrm{C}$ で 1 時間染着，そののち布をとり出して乾燥させる。乾嬠 後リン酸第三ナトリウムーボウ硝混合溶液（水 $1 l$ 中にリン酸第 三ナトリウム $10 \mathrm{~g}$ ，無东ボウ硝 $100 \mathrm{~g}$ を合む） $30 \mathrm{ml}$ でアルカ

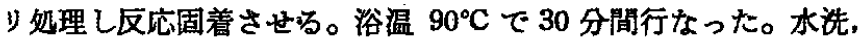
䡎蜗。

ナイロン（アミラン）絹の酸性染色の場合と同方法で行なっ た。

ビスコースレーヨン・䋵のアルカリ性染色の場合と同方法で行 なった。

以上の操作によって染着，办洗，乾燥した布の一部をとり染着 性を判定した。残りの布は $90^{\circ} \mathrm{C} て ゙ 20 \sim 30$ 分間ソーピングによ り加水分解染料の除去を行なった。このソーピング浴にはマルセ ルセッヶン $5 \mathrm{~g} / l$ と無水炭酸ナトリウム $1.5 \mathrm{~g} / l$ を含んでいる。 最後水洗, 乾燥し，この布を用いて色調，固着度，日光堅口ウ 度，洗たく堅口ウ度，摩擦堅口ウ度を調べた。

(昭和 35 年 4 月, 日本化学会第 13 年会 (東京) にて請演)

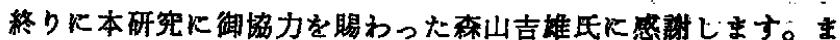
たナイロンょよび薬品の一部の寄贈をうけた東洋レーヨン，大東 化学工业所，佐友化学工業株式会社に感謝します。

\title{
長鍴アルキルベンゼンのクロルメチル化†
}

(昭和 36 年 6 月 30 日受理)

\section{草 野 邁・鈴木 恒 雄*}

\begin{abstract}
長鎖フルキルベンゼンの各種婹道体を合成して，合成条件ならびに生成物の性状を検討する目的で；まずての口ルメ チル化を試みた。フルキルベンゼンとして分枝ドデシルベンゼン (Alkane) を用い, 試薬（ホルムフルデヒドーホルマリ

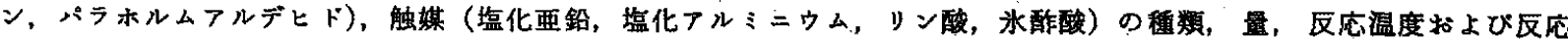
時間について，好収率でクロルメチル化物を得る条件を検討した。長銚てルキルベンゼンのクロルメチル化はかなり困難 で収率が低いことが報告されているが，アルケン $0.08 \mathrm{~mol}$ と対しバラホルムアルデヒド $0.16 \mathrm{~mol}$, 盟化重鉛 $0.15 \mathrm{~mol}$,

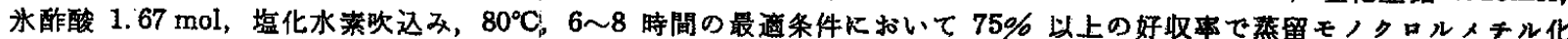
物を得ることができた。IR スべクトルがら生成物は主にパラ体で若干のオルト体を含むことが認められた。

また炭素数 $4 ， 8 ， 10 ， 12 ， 14 ， 16$ および 18 の直鎖了ルキルベンせンのクロルメチル化を行なった。

反応速度はフルキル鎮長の增大につれて漸減する。
\end{abstract}

\section{1 緒咅}

石油化学工業の発展に伴ない近くわが国でも大量の生産を見込 まれる側鎖を有する長鎖アルキルベンゼンの利用度を高めるため の基脴研究として，その各種誘導体を合成し；合成条件ならびル

†本報を「アルキルベンゼン誘等体の合成(第1 報)」とする。

* 工学院大学工業化学科：東京都新宿区角等.
生成物の性状を檢討することを企図し、ますとのクロルメチル化 について研究した。

芳香族化合物のクロルメチル化炕ついては既に多数の研究があ ク, Fuson と Mckeever の著名な総説1がある。しかしアルキ ルベンゼンの側鎖は $C_{6}$ 以下のものが多く，長鎖フルキルペンゼ

1) R.C.Fuson, C.H.Mckeever, Org. Reactions, Vol, 1, p. $63 \sim 90$. 